\title{
A CULTURA INQUISITÓRIA MANTIDA PELA ATRIBUIÇÃO DE ESCOPOS METAJURÍDICOS AO PROCESSO PENAL
}

\author{
Leonardo Augusto Marinho Marques* \\ José de Assis Santiago Neto**
}

SUMÁRIO: Introdução; 2 Sistemas Processuais Penais; 3 Teoria da RelaçãoJurídica e Socialismo Processual; 4 Modelo Constitucional de Processo e Processo Penal Democrático; 5 Considerações Finais; Referências.

RESUMO: A adoção de um modelo não inquisitorial passa pela construção de uma teoria do processo condizente com o Estado Democrático de Direito. Assim, a adoção teórica de modelos que retirem o julgador de uma posição de superioridade para colocá-lo em plano de igualdade em relação aos demais sujeitos é imprescindível. A revisão da teoria da relação jurídica, principalmente de sua vertente instrumental, que atribui ao processo escopos metajurídicos, no processo penal dá ao julgador funções que não devem lhe pertencer e o transformam em verdadeiro justiceiro em desconformidade com o processo democrático e aproximando o processo do modelo inquisitório.

PALAVRAS-CHAVE: Devido Processo Legal; Estado Democrático de Direito; Processo Penal Democrático.

\section{INQUISITORIAL CULTURE MAINTAINED BY META-JURIDICAL AIMS FOR PENAL PROCEDURES}

ABSTRACT: Adopting a non-inquisitorial model is part and parcel to a theory of process within the democratic state. It is important to adopt theoretical models that remove from the judging entity the superiority stance and place it on an equality plane with regard to the other subjects. A revision of theory in juridical relationship, especially in its instrument stance, attributes meta-juridical aims to the process and provides the judging entity with functions which do not belong to it. It is actually transformed into a true justice-enforcer not complying with the democratic process and makes it close to the inquisitorial model.

KEY WORDS: Legal Process; Democratic State; Democratic Penal Process.

\footnotetext{
Docente no Programa de Pós-Graduação Stricto sensu em Direito na Pontifícia Universidade Católica (PUCMinas) junto ao Mestrado e Doutorado, Brasil.

** Doutorando em Direito Processual pela Pontifícia Universidade Católica (PUC-Minas); Docente na Pontifícia Universidade Católica (PUC-Minas); E-mail: jose.santiago@terra.com.br.
} 


\section{LA CULTURA INQUISITORIA MANTENIDA POR LA ATRIBUCIÓN DE ALCANCE METAJURÍDICO AL PROCESO PENAL}

RESUMEN: La adopción de un modelo no inquisitorial pasa por la construcción de una teoría del proceso acorde al Estado Democrático de Derecho. Así, la adopción teórica de modelos que retiran el juez de una posición de superioridad para ponerlo en plan de igualdad en relación a los demás sujetos es imprescindible. La revisión de la teoría de la relación jurídica, principalmente de su vertiente instrumental, que atribuye al proceso un alcance metajurídico, en el proceso penal confiere al juez funciones que no deben pertenecerle y lo vuelven en verdadero justiciero en disconformidad con el proceso democrático y lo acercan al modelo inquisitorio.

PALABRAS-CLAVE: Debido Proceso Legal; Estado Democrático de Derecho; Proceso Penal Democrático.

\section{INTRODUÇÃO}

Direito e Poder sempre andaram juntos, normalmente sendo este representado por aquele. Ronaldo Brêtas de Carvalho Dias ${ }^{1}$ assinala que "o poder é a energia da ideia de direito, a força que tende a se introduzir no ordenamento jurídico positivo e que rege a vida das pessoas em sociedade". Contudo, consoante lição de José Alfredo de Oliveira Baracho², lembrando Montesquieu, o poder é uma experiência permanente e todo homem que possui poder é impulsionado a abusar do mesmo, assim, o poder para que não tenda ao arbítrio necessita ser contido pelo Direito. Nesse contexto, "a construção democrática do Estado assenta-se no exercício responsável do poder, para proteger os direitos dos governados" ${ }^{\text {. No }}$ Processo Penal esse fenômeno é vislumbrado de forma ainda mais clara, eis que o processo penal traz consigo a força máxima do poder do Estado sendo exercida contra o indivíduo, o poder de punir através da restrição daquilo que o indivíduo tem de mais precioso, seu tempo de vida, sua liberdade.

Ao longo de sua história o processo penal viveu fases pendulares, oscilando entre momentos de maior liberdade e maior repressão, ora prevalecendo ideias de segurança social e eficiência repressiva, ora sobressaindo ideias de maior proteção ao acusado e preservação de suas garantias ${ }^{4}$. Em cada uma dessas fases o sistema

\footnotetext{
${ }^{1}$ DIAS, Ronaldo Brêtas de Carvalho. Processo Constitucional e Estado Democrático de Direito. 2. ed. Belo Horizonte: Del Rey, p. 10-11.

2 BARACHO, José Alfredo de Oliveira. Processo Constitucional. Rio de Janeiro: Forense, 1984, p. 26.

3 BARACHO, José Alfredo de Oliveira. Processo Constitucional. Rio de Janeiro: Forense, 1984, p. 363.

${ }^{4}$ FERNANDES, Antônio Scarance. Processo Penal Constitucional. 6. ed. São Paulo: Revista dos Tribunais, 2010, p. 19.
} 
processual penal adotado sempre foi a máxima representação do momento vivido, sendo que em épocas em que o sistema assegurou maior liberdade foram adotados sistemas de partes, já em épocas de menor liberdade o sistema inquisitório prevaleceu.

Assim sendo, a adoção de um modelo inquisitório, vigente na Europa do século XI ao século XIX, fez com que o processo penal restasse concentrado nas mãos da figura do inquisidor. Nesse contexto, Oskar Von Bülow ao escrever sua clássica obra Teoria das Exceções Processuais e Dilações Probatórias buscou resgatar o processo como ato entre juiz autor e réu, na forma desenvolvida por Búlgaro no século XII, originando a teoria da relação jurídica, que concebeu o processo como instrumento da jurisdição. Contudo, ao manter o processo como instrumento da jurisdição, a referida teoria acabou mantendo o juiz no centro da relação processual e, consequentemente, mantendo acesa a chama da inquisição no Processo Penal.

Por sua vez, Cândido Rangel Dinamarco, ao adotar a teoria da relação jurídica, lançou mão da teoria instrumentalista do processo ao afirmar que o processo teria escopos metajurídicos a serem perseguidos pelo julgador.

Dessa forma, procuramos no presente texto desvelar o caráter inquisitório da teoria da relação jurídica, objetivando a construção de um Processo Penal de partes onde a decisão não seja obra exclusiva do julgador, mas construção comparticipada e dialógica entre todos os sujeitos do processo.

\section{SISTEMAS PROCESSUAIS PENAIS}

Segundo a doutrina majoritária ${ }^{5}$, o que diferencia o modelo inquisitório ${ }^{6}$ dos demais modelos processuais penais de partes ${ }^{7}$ é a gestão da prova, se a prova é gerida pelas partes teremos um modelo não inquisitorial, caso tenhamos a prova nas

\footnotetext{
5 Jacinto Nelson de Miranda Coutinho (COUTINHO, 2001, p. 28; 2009a, p. 109; 2009b, p. 254-255), Geraldo Prado (PRADO, 2006, p. 105), Aury Lopes Júnior (LOPES JUUNIOR, 2003, p. 1; 2013, p. 124; 2010, p. 157), Alexandre de Moraes da Rosa (ROSA, 2006, p. 323-324), Lênio Luiz Streck (STRECK, 2009, p. 119-120), Leonardo Augusto Marinho Marques (MARQUES, 2011, p. 480), Natalie Ribeiro Pletsch (PLETSCH, 2007, p. 68), Franco Cordero (CORDERO, 2000, p. 21; 1986, p. 44-45), Luigi Ferrajoli (FERRAJOLI, 2006, p. 520 e p. 530); Gilberto Thums (THUMS, 2006, p. 238); José de Assis Santiago Neto (SANTIAGO NETO, 2012, p. 95).

6 Não podemos falar em "processo inquisitório", mas em "procedimento inquisitório", eis que partimos do pressuposto de ser o processo procedimento desenvolvido em contraditório, sendo que a centralização das funções de acusar e julgar nas mãos de um só dos sujeitos processuais, na forma do modelo inquisitório, inviabiliza a existência do contraditório e, consequentemente, torna impossível de que o sistema inquisitório se torne um sistema processual, mas mero sistema procedimental.

7 Aqui trabalhamos com a existência de mais de um sistema que possa ser tido dentro do gênero processo penal de partes, que são todos aqueles que separam as funções de acusar, julgar e defender, sendo espécies o sistema acusatório, adversarial, processo penal democrático, modelos estes que comungam o mesmo eixo central de separação das funções de acusar, julgar e defender.
} 
mãos do juiz, estaremos diante de um modelo inquisitório. Assim, o procedimento inquisitório é realizado centralizado na figura de um único sujeito principal a quem compete a produção da prova e o julgamento, podendo ou não ter outros sujeitos que terão atuação em plano secundário. Por sua vez, a marca do processo não inquisitorial é sua realização mediante o actus trium personarum, ou seja, a decisão é construída entre autor, réu e julgador, que atuam em plano de igualdade na construção do provimento. Assim, a decisão penal no modelo democrático é fruto da construção endoprocessual através da atuação conjunta e paritária das partes e do julgador no mesmo palco e em condições de igualdade de diálogo ${ }^{8}$.

Geraldo Prado aponta que os séculos XIII e XIV marcaram a origem do modelo inquisitório, sendo que, consoante lição de Jacinto Nelson de Miranda Coutinho $^{10}$, a origem de tal sistema pode ser datada do ano de 1215 em razão do IV Concílio de Latrão, sendo que, segundo o mesmo autor, o embrião desse sistema havia sido lançado no ano de 1199 pela Bula Vergentis in senium do Papa Inocêncio III pela qual a heresia ao crime de lesa majestade. Nesse procedimento, toda a prova competiria ao inquisidor, sendo que o acusado de heresia somente teria direito a defensor caso não confessasse, mesmo após longas sessões de tortura, e nem houvesse qualquer prova da heresia, havendo testemunhas a favor do acusado. Nesse caso o defensor deveria ter raízes cristãs, sendo papel do advogado fazer o acusado de heresia confessar a acusação e pedir pena para o delito cometido ${ }^{11}$.

Nesse contexto, o procedimento inquisitorial acaba por afastar a presunção de não culpabilidade, eis que a acusação, a prova e o julgamento acabam centralizados nas mãos de um só intérprete, o inquisidor. Nesse quadro, se o mesmo sujeito acusa, produz as provas e julga, o acusado não tem nenhuma chance de sair vencedor, eis que a hipótese condenatória já fora proclamada vencedora antes mesmo do início do procedimento, fomentando o que Franco Cordero ${ }^{12}$ denominou de quadro mental paranoico, que se dá pelo primado da hipótese sobre os fatos. No processo inquisitório a verdade era perseguida a todo preço, sendo utilizados todos os meios disponíveis para tal desiderato, inclusive a tortura ${ }^{13}$.

\footnotetext{
8 SANTIAGO NETO, José de Assis. Estado democrático de direito e processo penal acusatório: a participação dos sujeitos no centro do palco processual. Rio de Janeiro: Lumen Juris, 2012.

9 PRADO, Geraldo. Sistema Acusatório: a conformidade constitucional das leis processuais penais. 4. ed. Rio de Janeiro: Lumnen Juris, 2006, p. 81.

${ }^{10}$ COUTINHO, Jacinto Nelson de Miranda. Sistema acusatório: cada parte no lugar constitucionalmente demarcado. Revista de informação legislativa. v. 183, ano 46, p. 103-115. Brasília: julho-setembro/2009, p. 104.

11 EYMERICH, Nicolau. Directorium Inquisitorum: manual dos inquisidores. 2. ed. Rio de Janeiro: Rosa dos Tempos; Brasília: Fundação Universidade de Brasília, 1993, p. 137-139.

${ }^{12}$ CORDERO, Franco. Guida alla procedura penale. Torino: UTET, 1986.

${ }^{13}$ KALED JR. Salah H. A busca da verdade no processo penal: para além da ambição inquisitorial. São Paulo: Atlas, 2013.
} 
O Brasil possui em seu ordenamento jurídico uma grande dicotomia. Enquanto a Constituição da República adotou, ainda que de modo implícito, o modelo constitucional-democrático de processo, ao assegurar a presunção de não culpabilidade (art. $5^{\circ}$, LVII), o devido processo constitucional (art. $\left.5^{\circ}, \mathrm{LIV}\right), \mathrm{o}$ contraditório e a ampla defesa (art. $5^{\circ}, \mathrm{LV}$ ), a separação das funções de acusar (art. 129), defender (art. 133 e 134) e julgar (art. 92 e seguintes), o código de processo penal, forjado sob a égide ditatorial do Estado Novo, possui estrutura inquisitória que, de tão arraigada, sequer as reformas pontuais foram capazes de mudar. Assim, o Código de Processo Penal, mesmo após as reformas promovidas nos últimos anos, não foi capaz de excluir de seu texto sua matiz autoritária e inquisitória, assegurando ao juiz amplo poder probatório, podendo produzir provas de ofício (art. 156), decretar prisão preventiva sem pedido dos demais sujeitos processuais (art. 311), discordar do pedido de arquivamento formulado pelo titular da ação penal (art. 28), entre outros dispositivos francamente inquisitórios. Verifica-se, pois, que a luz da Constituição deve permear a escuridão do autoritarismo através da interpretação do código à luz constitucional, contudo, na prática forense o que se vê é justamente o oposto, com a interpretação da constitucional sob o mais profundo breu do código vigente.

\section{TEORIA DA RELAÇÃO JURÍDICA E SOCIALISMO PROCESSUAL}

Após a derrocada do antigo regime e a ascensão do Estado de Direito, inicialmente sob o paradigma liberal, o poder do Estado passou a ter que ser controlado. Assim, sob o Estado Liberal o poder estatal era completamente reprimido e o Estado somente deveria intervir no mínimo possível ${ }^{14}$. Sob esse modelo o juiz era mero aplicador da norma criada pela função legislativa, chamado de "boca da lei", havendo o protagonismo das partes em detrimento do protagonismo judicial. Porém, o modelo de Estado abstencionista levou à exclusão da maioria, eis que a riqueza foi concentrada nas mãos de poucos e a maioria da população se viu obrigada a vender sua mão de obra ao troco de mínimos ganhos. Com a Primeira Guerra Mundial e crise de 1929, o Estado viu que não poderia deixar aos auspícios da "mão invisível" e era preciso intervir.

${ }_{14}$ HABERMAS, Jürgen. Direito e democracia: entre facticidade e validade. Rio de Janeiro: Tempo Universitário, 1997, v. 2. 
Com a derrocada do Estado Liberal, viu-se a necessidade de maior intervenção do Estado na vida das pessoas, sendo que ascendeu o paradigma Social. Segundo esse modelo, o Estado deveria funcionar como provedor, devendo distribuir aquilo que entendia necessário para a felicidade das pessoas ${ }^{15}$. Nesse modelo o juiz era distribuidor de direitos segundo suas concepções. O protagonismo judicial ganhou força sendo certo que o processo voltou a ser protagonizado e centralizado na figura do julgador, sendo as partes meros acessórios secundários para os quais o protagonista, segundo sua visão superior do mundo, distribuiria aquilo que entendia ser o "justo". Tal modelo levou a humanidade à barbárie dos sistemas totalitários, a Segunda Guerra Mundial mostrou ao mundo a face mais desumana da humanidade. O crescimento dos movimentos libertários dos anos 1960 mostrou que havia diferentes concepções de felicidade, mostrando que uma visão única do que seria o melhor para todos seria impossível, ascendendo o paradigma do Estado Democrático de Direito, modelo este que ainda se encontra em construção nos dias atuais.

Sob o prisma do Estado Social, o processo passou às mãos do juiz, dando ensejo ao socialismo processual, segundo o qual o julgador tinha por escopo a busca desenfreada por justiça e centralizava em suas mãos a tarefa de distribuí-la aos cidadãos. Assim, o juiz sob o Estado Social tinha duas funções primordiais, consoante ensina Dierle José Coelho Nunes ${ }^{16}$ : de educador, devendo instruir extraprocessualmente aos cidadãos em relação ao direito vigente; e de representante dos pobres, quando, endoprocessualmente, deveria assumir a representação do menos favorecido. Desse modo, o juiz, em nome de um senso de justiça no qual suas próprias concepções acabam prevalecendo, acaba por centralizar em sua figura a tarefa de aplicação da lei, em detrimento da participação das partes na construção do provimento.

Através do resgate da máxima de Búlgaro, jurista italiano do século XII, de que judicium est actum trium personarum: judiscis, actoris et rei (o processo é ato de três personagens: juiz, autor e réu), Bülow ${ }^{17}$, a publicar sua clássica obra Teoria das Exceções e dos Pressupostos Processuais, publicada originalmente no ano de 1868 , desenvolveu a teoria da relação jurídica, segundo a qual o processo seria

${ }_{15}$ HABERMAS, Jürgen. Direito e democracia: entre facticidade e validade. Rio de Janeiro: Tempo Universitário, 1997, v. 2.

${ }^{16}$ NUNES, Dierle José Coelho. Processo jurisdicional democrático. Curitiba: Juruá, 2009, p. 80.

17 BÜLOW, Oskar Von. La teoria de las excepciones procesales y los presupuestos procesales. Buenos Aires: Libreria El Foro, p. 10. 
uma relação jurídica entre autor, réu e juiz ${ }^{18}$. Com isso, a teoria da relação jurídica teve por mérito a descentralização do processo inquisitorial através da retomada da relação entre os três personagens do processo.

Apesar de Bülow ter escrito sua teoria destinada ao Processo Civil, afirmava que também poderia ser adotada pelo processo pena ${ }^{19}{ }^{19}$, contudo, os microssistemas do processo civil e do processo penal possuem estruturas diversas e que impedem que as teorias destinadas a uns possam ser trazidas, sem prejuízos, ao outro. Tal como ocorreu com a teoria da relação jurídica, centrada no conceito fundamental de lide, pode ser aplicada ao processo penal por faltar a esse ramo do direito tal conceito $^{20}$.

Contudo, apesar de resgatar o processo como um ato de três pessoas - juiz, autor e réu, Bülow buscava uma aplicação livre do direito, e, em certa medida, subjetiva dos juízes segundo sua sabedoria e sensibilidade ${ }^{21}$. O juiz, para Bülow, era um protagonista, o porta-voz do sentimento jurídico do povo, podendo criar o direito mesmo que contra a própria lei ${ }^{22}$.

Assim, apesar do resgate do processo como actum trium personarum, Bülow manteve o juiz como figura soberana, ao qual competiria fazer justiça e distribuir justiça, segundo sua concepção daquilo que seria justo para as partes segundo sua própria convicção de mundo. Com Bülow são lançadas as sementes do socialismo processual no âmbito da doutrina ${ }^{23}$, sendo que sua teoria serviu de base para a construção do Estado Social que ganhou força nos anos seguintes.

A teoria da relação jurídica sempre exerceu grande influência na produção legislativa brasileira. Desde que Liebman se radicou em São Paulo e lecionou na Faculdade de Direito do Largo de São Francisco (USP), tal teoria ganhou grande força no Brasil, sendo que seus alunos de maior destaque no país também passaram a gozar de grande prestígio, principalmente Ada Pellegrini Grinover e Cândido Rangel Dinamarco.

Derivada da teoria da relação jurídica, Dinamarco ${ }^{24}$ elaborou a denominada teoria instrumentalista do processo, segundo a qual o processo teria escopos

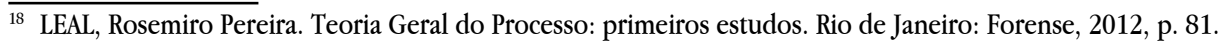

19 TORNAGHI, Hélio. A relação processual penal. 2. ed. São Paulo: Saraiva, 1987, p. 7.

${ }^{20}$ COUTINHO, Jacinto. A lide e o conteúdo do processo penal.

${ }^{21}$ NUNES, Dierle José Coelho. Processo jurisdicional democrático. Curitiba: Juruá, 2009, p. 101.

22 NUNES, Dierle José Coelho. Processo jurisdicional democrático. Curitiba: Juruá, 2009, p. 102.

${ }_{23}$ NUNES, Dierle José Coelho. Processo jurisdicional democrático. Curitiba: Juruá, 2009, p. 98.

24 DINAMARCO, Cândido Rangel. A instrumentalidade do processo. 5. ed. São Paulo: Malheiros, 1996.
} 
metajurídicos, nas esferas sociais, políticas e jurídicas, dentre ditos escopos do direito processual estaria o objetivo de fazer justiça social e corrigir as mazelas do povo, buscando a pacificação social, que, segundo Dinamarco, Cintra e Pelegrini ${ }^{25}$, seria o escopo magno da jurisdição. Nesse aspecto, a função jurisdicional e legislação possuiriam como escopo comum a busca da paz social ${ }^{26}$. Assim, a concepção instrumentalista coloca o processo como instrumento da jurisdição pelo qual esta realiza seus escopos metajurídicos na busca primordial pela pacificação, colocando o juiz no centro do palco processual e relegando aos demais sujeitos papel secundário de auxiliar o julgador em seu objetivo maior ${ }^{27}$, assim, tal teoria atribui ao magistrado a tarefa de fazer justiça através de seu instrumento (processo). Nessa senda, tal teoria coloca o juiz em posição de superioridade em detrimento dos demais sujeitos, é o juiz "órgão do Estado soberano, que se coloca acima de tudo e de todos (super omnia) e que proíbe os particulares de agir diretamente uns contra os outros, fazendo justiça pelas próprias mãos"28. Dessa forma, a colocação do juiz como ser superior impede que a decisão seja construída democraticamente pelas partes através do diálogo endoprocessual entre estas e o julgador, impedindo, consequentemente, a efetiva adoção de um modelo acusatório e fomentando a manutenção do sistema inquisitório eis que o procedimento passa a ter um único ator central.

A atribuição de escopos metajurídicos ao processo acaba por colocar nas mãos do juiz, como se ele fosse, ou pudesse ser, um ser superior em relação aos demais agentes processuais, a missão impossível de fazer justiça através do processo. Transforma-se o julgador, que deveria aplicar o Direito conforme lhe fora atribuído pelo povo (fonte única detentora do poder na Democracia), em justiceiro de toga, impedindo a implementação do contraditório e a consequente construção plural da decisão jurisdicional. Tal teoria não se orienta pelo eixo constitucional, não se preocupa com a legitimidade constitucional da decisão, apenas com seus resultados, negando que "o Processo é instrumentador da legitimidade da conduta do juiz e não mais um instrumento servil da Jurisdição" ${ }^{29}$.

${ }^{25}$ CINTRA, Antônio Carlos de Araújo; GRINOVER, Ada Pellegrini; DINAMARCO, Cândido Rangel. Teoria Geral do Processo. 23. ed. São Paulo: Malheiros, 2007, p. 30.

${ }^{26}$ DINAMARCO, Cândido Rangel. A instrumentalidade do processo. 5. ed. São Paulo: Malheiros, 1996, p. 159.

${ }^{27}$ SANTIAGO NETO, José de Assis. Estado democrático de direito e processo penal acusatório: a participação dos sujeitos no centro do palco processual. Rio de Janeiro: Lumen Juris, 2012, p. 29.

${ }_{28}$ TORNAGHI, Hélio. A relação processual penal. 2. ed. São Paulo: Saraiva, 1987, p. 141.

${ }^{29}$ LEAL, Rosemiro Pereira. Teoria Geral do Processo: primeiros estudos. Rio de Janeiro: Forense, 2012, p. 25. 
A leitura da exposição de motivos de nosso vigente Código de Processo Penal denota a preocupação daqueles que o fizeram ${ }^{30}$, em buscar através da lei processual, portanto, do processo, maior "eficiência e energia da ação repressiva"; vê-se em destaque como sendo o "espírito do Código" a seguinte passagem:

Do que vem de ser ressaltado, e de vários outros critérios adotados pelo projeto, se evidencia que este se norteou no sentido de obter equilíbrio entre o interesse social e o da defesa individual, entre o direito do Estado à punição dos criminosos e o direito do indivíduo às garantias e seguranças de sua liberdade.

Vê-se, pois, que o texto do Código de Processo Penal se norteia por interesses que não são jurídicos, dividindo de forma maniqueísta a sociedade entre criminosos e indivíduos, como se tal divisão fosse possível de ser realizada. O texto do código vigente é recheado de escopos que fogem completamente aos objetivos do processo penal, tais como os requisitos para se decretar a prisão preventiva, tais como garantia da ordem pública e garantia da ordem econômica.

O novo Código de Processo Penal, Projeto de Lei do Senado no 156/2009, segue o mesmo caminho, atribuindo ao juiz, em último grau, a tarefa de zelar pela efetividade da jurisdição. Ao tratar das cautelares, a exposição de motivos do novo CPP afirma que: "Com a formação do processo, já no âmbito da atuação jurisdicional, aí sim, poderá o juiz decretá-las até mesmo de ofício, pois lhe compete, em última análise, zelar pela efetividade da jurisdição" (negrito nosso).

Tais teorias exerceram grande influência nas reformas processuais realizadas nos últimos anos, sendo que as reformas realizadas nas últimas décadas, principalmente após a edição da EC 45, buscaram maior celeridade, confundindo celeridade com razoável duração do processo, e visando adequar ao discurso da "razoável duração do processo" (lida como processo cegamente célere) ao processo penal, normalmente utilizando das reformas como meio de dar pronta resposta a uma sociedade alarmada e amedrontada pela prática de algum crime amplamente noticiado pelos meios de comunicação de massa. Vale ressaltar que a razoável duração nada tem com a celeridade cega, a exigência constitucional é de que a prestação jurisdicional ocorra sem dilações indevidas, e, consequentemente, com

\footnotetext{
${ }_{30}$ Falar em "legislador" é esvaziar os interesses por trás da legislação através da neutralização proporcionada pela criação de um ente fictício que não existe se não na mente dos incautos que criam mitos para neles acreditar buscando explicações fáceis e desprovidas de qualquer senso crítico.
} 
todas as garantias processuais devidamente obedecidas ${ }^{31}$.

O Código de Processo Penal, gerado em pleno regime ditatorial de Getúlio Vargas (sob nítida influência do Código de Processo Penal Italiano de 1933, que, por sua vez, fora elaborado por Rocco, coordenado pelo então Ministro da Justiça Manzini e que tinha como Presidente o ditador Mussolini) possui nítida influência autoritária e adota o sistema inquisitório, tipicamente adotado pelos regimes autoritários. Dessa forma, o Código de Processo Penal brasileiro coloca a gestão probatória nas mãos do julgador, como até hoje ainda a mantém, mesmo após inúmeras reformas e a promulgação da Carta Cidadã de 1988. O CPP nasce com a missão bem delineada em sua exposição de motivos, de reduzir a criminalidade e colocar os direitos sociais sobre a tutela individual ${ }^{32}$. Veja-se bem, o estatuto processual penal já atribuía ao processo, em seu texto originário, objetivos extrajurídicos. Porém, a influência instrumentalista nas reformas (visto que o Código de Processo Penal brasileiro, de tão antiquado - deveria ser aposentado compulsoriamente eis que completou 70 anos de desserviços à democracia - é anterior à elaboração da teoria instrumentalista) foi amplamente utilizada para manter os escopos estranhos ao Direito atribuídos ao direito processual.

Assim sendo, o Código de Processo Penal adotou um modelo nitidamente inquisitório ${ }^{33}$, colocando nas mãos do juiz a gestão probatória. Porém, reformas pontuais não foram suficientes para mudar o sistema processual penal adotado, eis que não são capazes de mudar a estrutura do código ${ }^{34}$, somente um novo código, realmente desenhado sob os ares democráticos será capaz de mudar efetivamente o sistema processual penal brasileiro.

31 DIAS, Ronaldo Brêtas de Carvalho. Processo Constitucional e Estado Democrático de Direito. 2. ed. Belo Horizonte: Del Rey, 2012, p. 163.

32 Veja-se o que diz a exposição de motivos do vigente Código de Processo Penal: "De par com a necessidade de coordenaçã̃o sistemática das regras do processo penal num Código único para todo o Brasil, impunha-se o seu ajustamento ao objetivo de maior eficiência e energia da ação repressiva do Estado contra os que delinquem. As nossas vigentes leis de processo penal asseguram aos réus, ainda que colhidos em flagrante ou confundidos pela evidência das provas, um tão extenso catálogo de garantias e favores, que a repressão se torna, necessariamente, defeituosa e retardatária, decorrendo daí um indireto estímulo à expansão da criminalidade. Urge que seja abolida a injustificável primazia do interesse do indivíduo sobre o da tutela social. Não se pode continuar a contemporizar com pseudodireitos individuais em prejuízo do bem comum. $\mathrm{O}$ indivíduo, principalmente quando vê se mostrar rebelde à disciplina jurídico-penal da vida em sociedade, não pode invocar, em face do Estado, outras franquias ou imunidades além daquelas que o assegurem contra o exercício do poder público fora da medida reclamada pelo interesse social".

33 Em que pese o fato de existirem autores que afirmam que o modelo processual adotado no Brasil seria o misto e outros afirmarem que seria o modelo acusatório.

34 COUTINHO, Jacinto Nelson de Miranda. Um devido processo legal (constitucional) é incompatível com o sistema do CPP, de todo inquisitorial. In: PRADO, Geraldo; MALAN, Diogo (Coord.). Processo Penal e democracia: Estudos em homenagem aos 20 anos da Constituição da República de 1988. Rio de Janeiro: Lumnen Juris, 2009, p. 253-262; p. 254. 
Assim, as reformas processuais penais mantiveram a concepção instrumentalista, mantendo o processo sob a batuta do juiz e deixando as partes em plano de inferioridade no espaço processual. Porém, um novo Código de Processo Penal está em gestação no Congresso Nacional, sendo que, apesar dos nítidos avanços do projeto, ainda não será capaz de avançar para a efetiva adoção de um modelo acusatório de processo penal, eis que ainda possui forte influência da teoria da relação jurídica em sua concepção.

\section{MODELO CONSTITUCIONAL DE PROCESSO E PROCESSO PENAL DEMOCRÁTICO}

O modelo constitucional-democrático de processo deve ser fundado sob a presunção de não culpabilidade, que, em análise mais cuidadosa acaba por atribuir àquele que acusa, em regra ao Ministério Público, todo o ônus probatório do crime (fato típico, ilícito e culpável) imputado ao acusado, não competindo ao juiz a busca de provas para absolvição, eis que a presunção de não culpabilidade tem natureza relativa (iuris tantum) e somente deve ser afastada quando existirem provas da existência do crime e de sua autoria. A inexistência de provas deve(ria) levar à absolvição (manutenção da presunção de não culpabilidade), porém, a manutenção da gestão da prova nas mãos do julgador (sistema inquisitório) possibilita que este forme sua decisão antes de analisar a prova e, diante da conviç̧ão formada de véspera, o julgador passa a buscar elementos (até provas realizadas por sua vontade acusadora) para uma condenação retórica e afastada do contraditório, no que Franco Cordero denominou de quadro mental paranoico, no qual se verifica o primado da hipótese sobre o fato, partindo o julgador da hipótese mentalmente construída para buscar, ainda que de forma meramente retórica, os elementos que necessita para comprovar sua hipótese ${ }^{35}$. Dessa forma, a manutenção do modelo inquisitório e, via de consequência, da manutenção da gestão probatória nas mãos do julgador impossibilita a plenitude do contraditório e, consequentemente, da adoção de um modelo processual efetivamente democrático.

Por outro lado, tem-se que deve ser superada a distinção entre os sistemas processuais (acusatório e inquisitório) penais apenas pela singela separação das

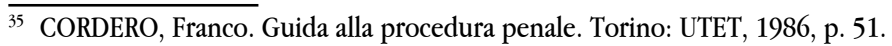


funções de acusar, julgar e defender. É preciso ver que tais sistemas foram modificados pelo passar dos anos e não mais podem ser vistos como foram no século XVIII, o moderno inquisitorialismo está presente de forma cada vez mais forte, através da gestão probatória, ou seja, inquisitório é o processo no qual o juiz concentra a gestão da prova em suas mãos e acusatório quando a dita gestão da prova está nas mãos das partes.

Diante disso, um processo inquisitório não há como se falar em contraditório, eis que o juiz detém todo poder probatório para proferir sua decisão na forma que lhe for mais conveniente, o juiz trabalha de forma solitária ${ }^{36}$, a falta do debate em contraditório faz com que se abra a porta para o pensamento paranoico ${ }^{37}$. Somente modelos não inquisitoriais que podem ser chamados de sistemas processuais, eis que neles existe um juiz imparcial e duas partes efetivamente parciais ${ }^{38}$, a existência de um processo de partes possibilita o contraditório, eis que cumpre às partes (e não ao solitário julgador!) a construção da decisão, o juiz participa da construção ${ }^{39}$, mas não é o único e nem superior aos demais construtores. No processo inquisitório a concentração de poderes nas mãos do julgador leva à inviabilização do contraditório e, consequentemente, do próprio processo. "O juiz passa de espectador para o papel de protagonista da atividade de resgatar subjetivamente a verdade do investigado (objeto), desprovido de contraditório, publicidade, com marcas indeléveis (cartas marcadas) no resultado, previamente colonizado" ${ }^{40}$.

Em que pese a teoria da Relação Jurídica, de Bülow ${ }^{41}$ (1868), ter resgatado o actum trium personarum, do jurista romano do século XII Búlgaro ${ }^{42}$, em nítido avanço em relação à centralização dos atos nas mãos de um só sujeito como se dava na inquisição clássica, tal avanço não pode ser tido como suficiente às exigências de um processo penal forjado no contraditório sob a égide do Estado Democrático de Direito, eis que a relação jurídica ainda concebe o juiz como estando em posição

\footnotetext{
${ }^{36}$ CORDERO, Franco. Guida alla procedura penale. Torino: UTET, 1986, p. 51.

${ }_{37}$ CORDERO, Franco. Procedimiento penal. Santa Fé de Bogotá: Temis, 2000, tomo 1, p. 23.

38 AROCA, Juan Montero. Principios del proceso penal: una explicación basada en la razón. Valencia: Tirant lo Blanch, 1997.

39 GONÇALVES, Aroldo Plínio. Técnica processual e teoria do processo. 2. ed. Belo Horizonte: Del Rey, 2012.

40 ROSA, Alexandre de Morais da. Decisão penal: a bricolage de significantes. Rio de Janeiro: Lumnen Juris, 2006, p. 55.

${ }^{41}$ BÜLOW, Oskar Von. La teoria de las excepciones procesales y los presupuestos procesales. Buenos Aires: Libreria El Foro.

${ }^{42}$ Apud LEAL, Rosemiro Pereira. Teoria Geral do Processo: primeiros estudos. Rio de Janeiro: Forense, 2012, p. 83 .
} 
de superioridade em relação aos demais sujeitos do processo ${ }^{43}$, sendo que "a relação jurídica de direito processual coloca o juiz como 'super-parte', de atuação preponderante no processo jurisdicional" ${ }^{44}$.

Assim, verifica-se a existência de uma aproximação entre a concepção instrumental do processo e um modelo inquisitivo, eis que ambas colocam o juiz no centro do palco processual, assim como se percebe a aproximação das teorias que adotam o processo como procedimento realizado em contraditório, calcadas sobretudo na obra do professor italiano Élio Fazzalari dos modelos acusatórios. O processo, quando usado como mero instrumento da jurisdição, atribui ao juiz, em ato solitário, a pacificação dos conflitos sociais tal qual é buscada pelo juiz-inquisidor, colocando o juiz como único responsável pela realização dos escopos metajurídicos que a própria teoria atribui ao processo, travestindo o julgador em justiceiro em busca da distribuição de justiça e a realização da pacificação social. A busca de escopos metajurídicos faz com que a teoria em questão tenha no modelo inquisitório um verdadeiro aliado, ambas inimigas da construção do Estado Democrático de Direito.

A marca do Estado Democrático de Direito é a participação da sociedade na tomada das decisões ${ }^{45}$, porém, a mera participação não é suficiente, a participação deve ser procedimentalizada, pois somente dessa forma é que se asseguraráa isonomia para a participação de todos os interessados na construção do provimento ${ }^{46}$. "Uma sociedade democrática é aquela que se permite à liberdade crítica, aos argumentos processualizados, que adota a isonomia discursiva e que não se monopoliza por um Estado que se sobrepõe à Comunidade Jurídica” ${ }^{\prime 47}$.

A função jurisdicional ${ }^{48}$ recebeu indevidamente a tarefa de ser a guardiã das promessas, tal tarefa que no Estado Liberal coube à função legislativa, no social restou centrada na função executiva/administrativa, agora se volta à figura do julgador. São depositadas no julgador as esperanças de ser o garantidor dos direitos,

43 TORNAGHI, Hélio. A relação processual penal. 2. ed. São Paulo: Saraiva, 1987, p. 141.

44 BARROS, Flaviane de Magalhães. (Re)Forma do Processo Penal. 2. ed. Belo Horizonte: Del Rey, 2009 , p. 12.

45 HABERMAS, Jürgen. Direito e democracia: entre facticidade e validade. Rio de Janeiro: Tempo Universitário, 1997, v. 2.

${ }^{46}$ LEAL, Rosemiro Pereira. Teoria processual da decisão jurídica. São Paulo: Landy, 2002, p. 131.

${ }^{47}$ DEL NEGRI, André. Controle de constitucionalidade no processo legislativo: teoria da legitimidade democrática. Belo Horizonte: Fórum, 2008, p. 86.

48 Na forma da obra do professor Ronaldo Brêtas de Carvalho Dias (2012, p. 22), preferimos o termo "função jurisdicional" vez que entendemos que o poder é uno e emanado de sua fonte única de legitimação: o povo. Assim, o poder não pode ser dividido, sendo que o que se divide são as funções do Estado para o exercício do poder que lhe foi outorgado pelo povo através da Constituição. 
como expôs Garapon ${ }^{49}$. Contudo, a tarefa de assegurar os direitos fundamentais não pode ser depositada em um intérprete privilegiado, devendo ser tarefa de todos os indivíduos na construção diária do Estado Democrático de Direito.

O processo no Estado Democrático de Direito deve ser percebido pelo prisma constitucional, nesse diapasão "não é apenas um direito instrumental, mas uma metodologia de garantia dos direitos fundamentais. Suas instituições estruturais (jurisdição, ação e processo) remetem-nos à efetivação dos direitos essenciais" ${ }^{50}$.

Assim sendo, um processo penal democrático deve ser marcado pela participação dos sujeitos na construção do provimento. Essa participação, por sua vez, somente será obtida com a colocação dos sujeitos no centro do palco processual, no qual participarão, juntamente com o julgador, da construção da decisão ${ }^{51}$. Um processo efetivamente de partes e democrático somente se obteria pela adoção de um modelo onde a decisão seja fruto da construção coparticipada daqueles que serão afetados por ela.

Porém, tem-se que somente uma mudança de lei não será capaz de alterar o processo penal inquisitorial, é imprescindível uma mudança de postura dos sujeitos processuais, que devem se assumir como reais construtores da decisão, de modo que assumam sua responsabilidade democrática na construção do provimento.

Dessa forma, para se construir um modelo efetivamente democrático de processo penal, é necessária a adoção de um sistema processual penal de partes, visando possibilitar a participação daqueles que serão afetados pelo provimento em sua efetiva construção. Por outro lado, o mito inquisitório oculto por trás das reformas instrumentais do processo penal somente será superado através de uma reforma profunda do processo penal (que de forma ululante passa por um novo código) onde seja adotado realmente um modelo constitucional de processo e pela adoção séria e efetiva do contraditório, que se possibilitará um processo penal efetivamente democrático. Dessa forma, a manutenção de concepções que têm base na relação jurídica, principalmente atribuindo escopos metajurídicos ao processo e a gestão da prova nas mãos do juiz significa manter o processo penal brasileiro distante dos termos constitucionais e cada vez mais distante das exigências do Estado Democrático de Direito.

49 GARAPON, Antonie. O juiz e a democracia: o guardião das promessas. 2. ed. Rio de Janeiro: Revan, 2001.

${ }^{50}$ BARACHO, José Alfredo de Oliveira. Direito Processual Constitucional: aspectos contemporâneos. Belo Horizonte: Fórum, 2008, p. 47.

51 SANTIAGO NETO, José de Assis. Estado democrático de direito e processo penal acusatório: a participação dos sujeitos no centro do palco processual. Rio de Janeiro: Lumen Juris, 2012. 
Ao se atribuir ao processo penal escopos, objetivos metajurídicos, como o de pacificação social e garantia da ordem pública e social, coloca-se nas mãos do julgador uma tarefa que não lhe compete em uma estrutura democrática. Tal fato acaba fazendo do juiz não um julgador mas um justiceiro a quem busca a todo custo a realização dos ditos escopos e não a construção democrática e endoprocessual da decisão. Nesse contexto, o juiz travestido pelos escopos de "fazer justiça", "pacificar a sociedade", etc., acaba por deixar a postura de imparcialidade que lhe competiria, chamando para si todo o conteúdo do processo, retomando a centralização dos poderes endoprocessuais e expulsando os demais sujeitos do centro do palco processual. Dessa forma, sob nobres, porém inalcançáveis, objetivos o juiz deixa de ser um julgador imparcial para voltar à função de inquisidor, inviabilizando a construção democrática de decisão.

No processo penal democrático o juiz não é um justiceiro, mas um garantidor dos direitos fundamentais dos sujeitos processuais, inclusive do acusado, devendo assegurar que a sentença seja efetivamente construída pela participação das partes (autor - Ministério Público ou querelante - e acusado - defesa técnica e autodefesa). Assim sendo, o juiz deve dividir com as partes o espaço processual, sendo o provimento o produto do diálogo endoprocessual entre acusação, defesa e julgador e não mais o resultado de um ato solitário do juiz conforme sua consciência.

A manutenção de escopos metajurídicos ao processo penal fomenta a centralização das funções nas mãos do julgador e mantém o juiz como responsável a buscar objetivos que não podem ser alcançados pelo processo. Dessa forma, acaba por favorecer a manutenção de uma cultura inquisitorial e, o que é ainda mais perigoso ao Estado Democrático de Direito, da mentalidade inquisitória de seus sujeitos que se acostumaram a serem conduzidos por um ente superior que busca atingir aos anseios metajurídicos que foram indevidamente inseridos como sendo objetivos do processo.

A adoção dos ditos escopos metajurídicos, adotados como verdades absolutas e indiscutíveis, acaba contaminando a mentalidade dos operadores do Direito Processual Penal, fazendo com que estes, sem perceber, passem a adotar uma mentalidade inquisitória na constante busca de pacificação social ou de garantir a malfadada ordem pública. Nesse contexto, acaba-se reproduzindo o discurso de que o processo penal deve buscar atingir os ditos escopos metajurídicos de forma acrítica e sem que se perceba que dessa forma são forjadas mentes inquisidoras que 
contribuem para que o processo penal cada vez menos se concentre na divisão de funções entre todos seus sujeitos para concentrar todo poder nas mãos do julgador.

Dessa forma, o processo penal padece de séria enfermidade teórica ao buscar sua base teórica no processo civil, principalmente por importar dele escopos metajurídicos que sequer poderiam ser aceitos naquele ramo do direito processual. Assim, deve o processo penal se afastar de objetivos que não sejam jurídicos, devendo se fundar em ser o meio de legitimação da decisão que se fundamentará no debate entre todos seus sujeitos realizado através do contraditório.

\section{CONSIDERAÇÕES FINAIS}

Concluímos, portanto, que conceber o processo como instrumento da jurisdição e a atribuição de escopos metajurídicos à relação processual, como é feito pelos adeptos da teoria da relação jurídica em sua vertente desenvolvida pela denominada teoria instrumentalista do processo, acaba colocando o juiz em posição de superioridade em relação às partes. Dessa forma, resta inviabilizado o diálogo necessário para a construção processual do provimento final e torna-se impossível que a sentença seja fruto da participação dos sujeitos através do constante diálogo processualizado.

O processo penal sob a égide do Estado Democrático de Direito não se satisfaz mais nem com o protagonismo judicial (Estado Social) e nem mais com o protagonismo das partes (Estado Liberal). O processo penal democrático deve ser 0 palco do diálogo entre todos seus sujeitos, cada um exercendo seu papel, mas todos igualmente responsáveis pela construção do provimento final.

Somente pelo diálogo e pelo policentrismo processual, onde os sujeitos do processo cada qual desempenhando seu papel e em contraditório, é que se viabilizará um processo efetivamente protagonizado por todos seus sujeitos, tal qual exige o processo acusatório.

Por fim, somente o abandono completo da relação jurídica e, consequentemente, da atribuição de escopos metajurídicos ao processo, é que possibilitará a retirada do julgador da posição de superioridade em relação aos demais sujeitos processuais, colocando-o em posição de igualdade e possibilitando que a sentença deixe de ser um ato solitário de um intérprete privilegiado da norma para 
se tornar no resultado produzido em contraditório entre todos aqueles que sofrerão os efeitos da decisão. Somente assim é que se possibilitará a efetiva realização do sistema acusatório que é o único sistema processual penal em conformidade com os ditames do Estado Democrático de Direito.

\section{REFERÊNCIAS}

AROCA, Juan Montero. Principios del proceso penal: una explicación basada en la razón. Valencia: Tirant lo Blanch, 1997.

BARACHO, José Alfredo de Oliveira. Processo Constitucional. Rio de Janeiro: Forense, 1984.

BARACHO, José Alfredo de Oliveira. Direito Processual Constitucional: aspectos contemporâneos. Belo Horizonte: Fórum, 2008.

BARROS, Flaviane de Magalhães. (Re)Forma do Processo Penal. 2. ed. Belo Horizonte: Del Rey, 2009.

BÜLOW, Oskar Von. La teoria de las excepciones procesales y los presupuestos procesales. Buenos Aires: Libreria El Foro, [19--].

CINTRA, Antônio Carlos de Araújo; GRINOVER, Ada Pellegrini; DINAMARCO, Cândido Rangel. Teoria Geral do Processo. 23. ed. São Paulo: Malheiros, 2007.

CORDERO, Franco. Guida alla procedura penale. Torino: UTET, 1986.

CORDERO, Franco. Procedimiento penal. Santa Fé de Bogotá: Temis, 2000. Tomo 1.

COUTINHO, Jacinto Nelson de Miranda. Introdução aos princípios gerais do direito processual penal brasileiro. Revista de Estudos Criminais, Porto Alegre, n. 1, p. 26-51, 2001.

COUTINHO, Jacinto Nelson de Miranda. Sistema acusatório: cada parte no lugar constitucionalmente demarcado. Revista de informação legislativa, v. 183, v. 46, p. 103-115, jul./set. 2009. 
COUTINHO, Jacinto Nelson de Miranda. Um devido processo legal (constitucional) é incompatível com o sistema do CPP, de todo inquisitorial. In: PRADO, Geraldo; MALAN, Diogo (Coord.). Processo Penal e democracia: estudos em homenagem aos 20 anos da Constituição da República de 1988. Rio de Janeiro: Lumen Juris, 2009. p. 253-262.

DEL NEGRI, André. Controle de constitucionalidade no processo legislativo: teoria da legitimidade democrática. Belo Horizonte: Fórum, 2008.

DIAS, Ronaldo Brêtas de Carvalho. Processo Constitucional e Estado Democrático de Direito. 2. ed. Belo Horizonte: Del Rey, 2012.

DINAMARCO, Cândido Rangel. A instrumentalidade do processo. 5. ed. São Paulo: Malheiros, 1996.

EYMERICH, Nicolau. Directorium Inquisitorum: manual dos inquisidores. 2. ed. Rio de Janeiro: Rosa dos Tempos; Brasília: Fundação Universidade de Brasília, 1993.

FERNANDES, Antônio Scarance. Processo Penal Constitucional. 6. ed. São Paulo: Revista dos Tribunais, 2010.

FERRAJOLI, Luigi. Direito e razão: teoria do garantismo penal. 2. ed. São Paulo: Revista dos Tribunais, 2006.

GARAPON, Antonie. O juiz e a democracia: o guardião das promessas. 2. ed. São Paulo: Revan, 2001.

GONÇALVES, Aroldo Plínio. Técnica processual e teoria do processo. 2. ed. Belo Horizonte: Del Rey, 2012.

HABERMAS, Jürgen. Direito e democracia: entre facticidade e validade. Rio de Janeiro: Tempo Universitário, 1997, v. 2.

KALED JR., Salah H. A busca da verdade no processo penal: para além da ambição inquisitorial. São Paulo: Atlas, 2013.

LEAL, Rosemiro Pereira. Teoria processual da decisão jurídica. São Paulo: Landy, 2002. 
LEAL, Rosemiro Pereira. Teoria Geral do Processo: primeiros estudos. Rio de Janeiro: Forense, 2012.

LOPES JÚNIOR, Aury. Juízes inquisidores? e paranóicos. Uma crítica a partir da jurisprudência do Tribunal Europeu de Direitos Humanos. Boletim do Instituto Brasileiro de Ciências Criminais - IBCCRIM, São Paulo, n. 127, jun. 2003. Disponível em: <www.ibccrim.org.br> Acesso em: 09 mar. 2011.

LOPES JÚNIOR, Aury. Introdução crítica ao Processo Penal (fundamentos da instrumentalidade constitucional). 5. ed. Rio de Janeiro: Lumnen Juris, 2010.

LOPES JÚNIOR, Aury. Direito Processual Penal. 10. ed. Rio de Janeiro: Saraiva, 2013.

MARQUES, Leonardo Augusto Marinho. A hiper-racionalidade inquisitória. BONATO, Gilson (Org.). Processo Penal, Constituição e crítica (Estudos em homenagem ao Prof. Dr. Jacinto Nelson de Miranda Coutinho). Rio de Janeiro: Lumnen Juris, 2011, p. 475-485.

NUNES, Dierle José Coelho. Processo jurisdicional democrático. Curitiba: Juruá, 2009.

PLETSCH, Natalie Ribeiro. Formação da prova no jogo processual penal: o atuar dos sujeitos e a construção da sentença. São Paulo: IBCCRIM, 2007.

PRADO, Geraldo. Sistema Acusatório: A conformidade constitucional das leis processuais penais. 4. ed. Rio de Janeiro: Lumnen Juris, 2006.

ROSA, Alexandre de Morais da. Decisão penal: a bricolage de significantes. Rio de Janeiro: Lumnen Juris, 2006.

ROSA, Alexandre de Morais da. Guia compacto do Processo Penal conforme a teoria dos jogos. Rio de Janeiro: Lumen Juris, 2013.

SANTIAGO NETO, José de Assis. Estado democrático de direito e processo penal acusatório: a participação dos sujeitos no centro do palco processual. Rio de Janeiro: Lumen Juris, 2012. 
STRECK, Lênio Luiz. Novo Código de Processo Penal: O problema dos sincretismos de sistemas (inquisitorial e acusatório). Revista de informação legislativa, Brasília, v. 183 , n 46, p. 117-139, jul./set. 2009.

THUMS, Gilberto. Sistemas processuais penais: tempo - tecnologia - dromologia - garantismo. Rio de Janeiro: Lumnen Juris, 2006.

TORNAGHI, Hélio. A relação processual penal. 2. ed. São Paulo: Saraiva, 1987.

Recebido em: 30 de julbo de 2015 Aceito em: 07 de agosto de 2015 